\title{
Ruga Policy And National Integration: Implications For Guidance And Counselling
}

\author{
Dr. Chikwe Agbakwuru \\ Department of Educational Psychology, Guidance and Counselling, \\ University of Port Harcourt, Nigeria \\ Dr. C. G. Awujo \\ Department of Education Psychology, Guidance and Counselling, \\ University of Port Harcourt, Nigeria
}

\begin{abstract}
This study investigated the impact of ruga policy on national integration in Nigeria. The study was carried out in South-South, South-East, SouthWest and North-Central geo-political zones of Nigeria. The sample consist of 4,000 literate adults who were composed through accidental sampling technique from markets, motor parks and federal secretariats in Port Harcourt, Owerri, Lagos and Makurdi. Relevant data for answering the research questions were collected from the sample through the administration of copies of Ruga and National Integration Challenges Questionnaire by the researchers and six research assistants. The reliability co-efficient of this questionnaire was established with 50 subjects from University of Port Harcourt through the Cronbach Alpha method and it was $0.81,0.80,0.87$ and 0.83 for the three sub-sections of the instrument and the overall. Data analysis was carried out with mean and standard deviation test statistics. The results show that ruga policy to a very great extent impact negatively on peaceful co-existence, and sense of trust among ethnic groups. It also heightens fear and anxiety in the country. These findings were discussed, the counselling implications stated and some recommendations were also made. One of the recommendations is that the federal government should cancel the ruga policy in Nigeria.
\end{abstract}

\section{BACKGROUND OF THE STUDY}

One of the most controversial federal government policies in recent time is the ruga policy. Ruga is a Hausa word which means cow settlement (Bankole, 2019). According to Toromade (2019), ruga is a Fulani word which also means cow settlement. Weather Hausa or Fulani word, one generally accepted thing is that ruga refers to cow settlement. The Federal Government of Nigeria led by President Muhammadu Buhari came up with the ruga policy in May, 2019 as rural grazing area. The policy goal is to map out settlement area for herdsmen and cattle in each state of the federation. Within this reserved grazing area, they are to be provided with pasture, water, health facilities, schools, security, road networks, veterinarian clinics, markets as well as processing firms that would make refined products from meat, milk and other cattle by products (Bankole, 2019). The federal government believes that the implementation of the ruga policy will achieve the following objectives: 
- It will bring to an end the lingering herders-farmers conflicts and its attendant negative consequences.

- Ruga will stop the age long open grazing which is not in tender with modern method of animal husbandry.

Although, these objectives are noble, most Nigerians and socio-cultural organizations outside the Hausa/Fulani ethnic group are however apprehensive, suspicious and fearly of the motive of the government in coming up with the ruga policy. The Middle Belt Forum clearly expressed its fears and apprehension by vehemently opposing the policy and claiming that it is a plot to import criminal Fulan from within and neighbouring countries to settle them in their communities in order to change the demography for political, social and economic advantage in pursuit of the fulanisation agenda of the federal government (Adetayo, Onojoghen, Muhammed, Ogundele, Adepegba \& Baiyewu, 2019). Other socio-cultural organizations such as Ohaneze Ndi Igbo, Afenifere of the Yorubas as well as Pan Niger Delta Forum (PANDEF) also opposed the policy vehemently.

The apprehension of many Nigerians and socio-cultural organizations is anchored on their perception of the following issues:

- The parallel and hasty formulation of the ruge policy even when the National Livestock Transformation Plan 2018-2027, approved by the National Economic Council has already commenced.

- The ambitious and aggressive move of the federal government to acquire ancestoral land of Nigerians and give same to the herdsmen for their private business of cattle rearing.

- The visa free policy of the federal government to all Fulanis in West Africa and indeed Africa to enter and reside in Nigeria.

- The rise in rape, attacks, kidnappings and destruction of lives and property of the natives by Fulani herdsmen since 2015 and the effrontery of Miyetti Allah Cattle Breeders Association.

- The apparent silence of President Muhammadu Buhari administration in condemning, arresting and prosecuting his Fulani kinsmen for their atrocities against their fellow Nigerians.

- The appointment of mostly northern Muslims by the president to head federal security arms, agencies and institutions in the country.

- The unwillingness of President Muhammadu Buhari to declare Fulani herdsmen as a terrorist group even after the Global Terrorism Index (2018) has named it as the fourth most deadly terrorist group in the world.

- Perceived inslamization agenda of Nigeria by the President.

- The fear of Fulani domination and conquest as ruga seeks to create territories for them all over the country.

These fears, suspicions and apprehensions seem to have impacted negatively on national integration which Ojo (2009) defined as the process of unifying a society which tends to make it a harmonious city based upon an order its members regard as equitably harmonious. According to the same source, national integration is a state of the mind or disposition of members of any given society to be cohesive, to act together and to be committed to mutual programmes. The key paths to its achievement are building and maintaining confidence and security in the society through good 
governance, reduction of social exclusion and development of inclusive society as well as the creation of suitable environment for all round development.

The need for the federal government to pursue only policies that will promote national integration cannot be overemphasized because it is the only path to unity, cohesiveness and solidarity which are pre-requisites to peaceful co-existence and progress of any nation - state. Furthermore, national integration enhances the pursuit of national interest which advances the course of national growth and development. In the absence of it, component parts of the nation - state pursues parochial and sectional interests. Most often as it is the case in Nigeria, these parochial and sectional interests lead to mal-integration which manifests through unnecessary frictions, tensions and conflicts which further draw back the wheel of progress in the country.

National integration is a state of affair that is achieved in a peaceful and all inclusive condition. It is not achieved in an environment that is characterized by inter-ethnic group suspicion, distrust, fear, hatred, injustice, perceived domination and the likes (Agbakwuru, 2003). These negative conditions are associated with ruga policy in Nigeria. This is why many well meaning citizens have decried the policy framework by the federal government. In fact, it is speculated that the policy has done more harm than good to national integration than any other policy of the federal government in recent times. Sadly, there is an apparent lack of research reports on the extent of its harmful effects on national integration as what abound in literature concerning ruga is mere opinion of individuals and groups. This study was therefore embarked upon to fill this gap in knowledge. Therefore, the problem of the study is "to what extent has ruga policy impacted negatively on national integration in Nigeria"?

This study was guided by the following research questions;

1. To what extent has ruga policy weakened the spirit of peaceful co-existence in Nigeria?

2. To what extent has ruga policy destroyed the sense of trust between Hausa/Fulanis and other Nigerians?

3. To what extent has ruga policy heightened fears in Nigeria?

\section{METHODOLOGY}

The design of this study is descriptive survey and it was carried out in four towns in South-East, south-south, south-west and north-central geo-political zones of Nigeria. These towns are Owrri, Port Harcourt, Lagos and Makurdi. These geo-political zones were chosen because they vehemently opposed the ruga policy. In each of the towns chosen for this study, 1000 respondents were drawn for the study. Thus the sample of the study is 4000 literate adult respondents. The accidental sampling technique was adopted in composing this sample because the population is unstable hence randomization cannot apply.

The instrument for data collection is a researchers' developed questionnaire titled "Ruga and National Integration Challenges Questionnaire (RNICQ). It is a non-cognitive instrument consisting of sections A and B. Section A elicits demographic information while section B elicits information for answering the three research questions being investigated. This section contains 22 items which are further subdivided into three sub-sections corresponding with the three research questions. This section was designed in the pattern of a four point likert - type scale of disagree (D), Agree (A), strongly agree (SA) and very strongly agree (VSA) with scoring points of 1,2,3 and 4 points 
respectively. The reliability coefficient of this instrument was ascertained through the Cronbach Alpha method with 50 subjects from the University of Port Harcourt. The obtained reliability coefficient for the three subsections of section B and the grand are $0.81,0.80,0.87$ and 0.83 respectively.

Relevant data for answering the research questions were collected from the sample through the direct method of administering copies of the questionnaire to them in motor parks, markets and federal government secretariats in each of the four towns earlier mentioned. The administration of copies of the questionnaire was carried out by the researchers and six research assistants. These places were chosen for distribution of the questionnaire because people from diverse states and religious/cultural persuasions in Nigeria abound in them. This condition was considered necessary in order to generate data that will produce results which will be reasonably generalized in Nigeria. Data analysis was carried out with mean and standard deviation. In interpreting the results, 2.50 was chosen as criterion point. Thus, any item with less than 2.50 was taken as low extent while item with 2.50 to 2.99 were taken as high extent. Finally, items that scored 3.00 to 4.00 were seen as very high extent.

\section{RESULTS}

Results of data analysis are presented in the following tables;

Table 4.1: $\bar{X}$ and S.D. analysis of the impact of ruga policy on spirit of peaceful co-existence in Nigeria.

\begin{tabular}{|c|l|c|c|}
\hline $\mathbf{S} / \mathbf{N}$ & \multicolumn{1}{|c|}{ Items } & \multicolumn{1}{|c|}{$\boldsymbol{|}$} & \multicolumn{1}{|c|}{ S.D. } \\
\hline $\mathbf{1}$ & $\begin{array}{l}\text { Since the Fulani herdsmen are committing crimes against humanity, they } \\
\text { and their ruga should not exist in our territory }\end{array}$ & 3.85 & 0.59 \\
\hline $\mathbf{2}$ & $\begin{array}{l}\text { The government should develop ruga in the core northern states and } \\
\text { restrict the herdsmen there. }\end{array}$ & 3.90 & 0.36 \\
\hline $\mathbf{3}$ & $\begin{array}{l}\text { Cattle rearing is the business of the core northern states therefore, ruga } \\
\text { should be restricted there. }\end{array}$ & 3.90 & 0.38 \\
\hline $\mathbf{4}$ & The Fulani herdsmen and their ruga are not needed in our territory & 3.83 & 0.35 \\
\hline \multicolumn{2}{|c}{ Grand Mean Score } & $\mathbf{3 . 8 7}$ & \\
\hline
\end{tabular}

The result on table I show that the mean scores of all the items as well as the grand mean score far exceeded 2.99. The conclusion which was drawn from this result is that to a very great extent, ruga policy has impacted negatively on the spirit of peaceful co-existence in Nigeria. 
Table 4.2: $\bar{X}$ and S.D. analysis of the impact of ruga policy on sense of trust between the Fulani and other Nigerians.

\begin{tabular}{|c|l|c|c|}
\hline $\mathbf{S} / \mathbf{N}$ & \multicolumn{1}{|c|}{ Items } & \multicolumn{1}{|c}{} & \multicolumn{1}{|c}{ S.D. } \\
\hline $\mathbf{1}$ & $\begin{array}{l}\text { The Fulani have evil intentions against other Nigerians in their ruga } \\
\text { policy }\end{array}$ & 3.69 & 0.40 \\
\hline $\mathbf{2}$ & $\begin{array}{l}\text { The ruga policy has eroded one's confidence in the Fulani led Federal } \\
\text { Government of Nigeria }\end{array}$ & 3.38 & 0.51 \\
\hline $\mathbf{3}$ & $\begin{array}{l}\text { Because of the ruga and similar policies of the President Buhari } \\
\text { administration, one can no longer trust the Fulani. }\end{array}$ & 3.11 & 0.56 \\
\hline $\mathbf{4}$ & $\begin{array}{l}\text { Ruga policy makes one very uncomfortable living around many Fulani } \\
\text { herdsmen. }\end{array}$ & 3.67 & 0.52 \\
\hline $\mathbf{5}$ & $\begin{array}{l}\text { The sight of Fulani herdsmen around one quickly reminds one of their } \\
\text { terror and crimes against humanity. }\end{array}$ & 3.75 & 0.60 \\
\hline $\mathbf{6}$ & $\begin{array}{l}\text { It will be disastrous to allow ruga in our territory } \\
\text { Grand Mean Score }\end{array}$ & 3.89 & 0.30 \\
\hline \multicolumn{2}{|l}{$\mathbf{3 . 5 7}$} & \\
\hline
\end{tabular}

The result on table two shows that all the mean scores are greater than 2.99. The conclusion which was drawn from this result is that ruga policy has to a very great extent impacted negatively on the sense of trust between the Fulani and other Nigerians.

Table 4.3: $\bar{X}$ and S.D. analysis of the impact of ruga policy on fears in Nigeria

\begin{tabular}{|c|l|c|c|}
\hline $\mathbf{S} / \mathbf{N}$ & \multicolumn{1}{|c|}{ Items } & $\overline{\boldsymbol{X}}$ & $\mathbf{S . D .}$ \\
\hline $\mathbf{1}$ & Ruga will lead to genocide in Nigeria & 3.90 & 0.31 \\
\hline $\mathbf{2}$ & $\begin{array}{l}\text { It will lead to the domination of the natives by Fulani } \\
\text { ethnic group }\end{array}$ & 3.88 & 0.30 \\
\hline $\mathbf{3}$ & $\begin{array}{l}\text { Ruga is a ploy to displace original land owners and give it } \\
\text { to Fulanis }\end{array}$ & 3.89 & 0.31 \\
\hline $\mathbf{4}$ & $\begin{array}{l}\text { Ruga will lead to more kidnappings and rape by the } \\
\text { herdsmen }\end{array}$ & 3.90 & 0.30 \\
\hline $\mathbf{5}$ & $\begin{array}{l}\text { It will lead to greater acts of murder by the Fulani } \\
\text { herdsmen }\end{array}$ & 3.87 & 0.32 \\
\hline $\mathbf{6}$ & Ruga is a ploy to Islamize Nigeria & 3.19 & 0.49 \\
\hline $\mathbf{7}$ & $\begin{array}{l}\text { Ruga will lead to heightened level of food scarcity in } \\
\text { Nigeria }\end{array}$ & 3.89 & 0.32 \\
\hline $\mathbf{8}$ & Ruga is a ploy of territorial expansion by the Fulani & 3.76 & 0.40 \\
\hline $\mathbf{9}$ & $\begin{array}{l}\text { Ruga will impoverish original land owners and enrich the } \\
\text { Fulani }\end{array}$ & 3.84 & 0.39 \\
\hline $\mathbf{1 0}$ & $\begin{array}{l}\text { Ruga policy is a pronouncement of war against the native } \\
\text { land owners }\end{array}$ & 3.45 & 0.42 \\
\hline $\mathbf{1 1}$ & Ruga is an invitation to crisis in Nigeria & 3.70 & 0.35 \\
\hline $\mathbf{1 2}$ & Ruga will pave the way for our conquest by the Fulani & 3.69 & 0.37 \\
\hline & $\quad$ Grand Mean Score & $\mathbf{3 . 7 5}$ & \\
\hline
\end{tabular}

The result on table 3 shows that the mean scores of the 12 items and the grand mean score are greater than 2.99. The conclusion which was drawn from this result is that to a very great extent, ruga policy has heightened fears in Nigeria. 
Hamburg, I. (2020). Supporting Digital Innovations by Interdisciplinary Entrepreneurial Learning. Advances in Social Sciences Research Journal, 7(3) 8-17.

\section{Discussion of Findings}

The findings of this study show that Ruga policy to a very great extent impact negatively on peaceful co-existence and sense of trust among various ethnic groups in Nigeria. The result also shows that ruga policy also hightens fears and anxiety among Nigerians. These findings vindicate the apprehension of many Nigerians regarding the policy. It further gives credence to the opinion of many Nigerians particularly from southern and middle belt that ruga policy is a major threat to national integration in Nigeria. Looking further at the standard deviation scores of the respondents for each of the items, it is obvious that they are low. This means that the respondents did not differ widely in their responses to each of the items in the questionnaire.

\section{RECOMMENDATIONS}

In the light of the findings of this study, the following recommendations are hereby made;

1. The federal government should not only suspend the ruga policy but cancel it because of its negative impact on national integration and cohesion.

2. The federal government should evolve measures and policies that will build mutual trust among Nigerians from different ethnic groups.

3. The federal government should be fair and just in dealing with all sections and ethnic groups in the country. This measure is very important in order to promote peaceful coexistence and national integration in the country.

\section{Implications for Guidance and Counselling}

Professional guidance counsellors can contribute immensely to the promotion of national integration in Nigeria in the following ways;

\section{Promotion of community guidance services}

This will help Nigerians from different ethnic groups to recognize the irrationality in their feelings, attitudes and stereotypes towards their fellow country men from other ethnic groups. When humuour is applied in the community guidance, it will encourage communication on sensitive matters, give insight into conflicts, help people to overcome a stiff and formal social style, facilitate the acting out of feelings or impulses in a safe nonthreatening way and put individuals in a frame of mind more conducive to effective interchanges with others (McGhee and Hershkowitz cited in Agbakwuru, 2012).

\section{Sensitization and enlightenment campaigns}

These are aimed at creating awareness on the obstacles to national integration and how to surmount them. It is also aimed at sensitizing the government on the need to eschew nepotism and favoritism in dealing with the citizens alike and at all levels.

\section{Promotion of mass literacy}

This will help to eradicate ignorance, superstitious beliefs, illiteracy and misinformation which are impediments to national integration and cohesion in Nigeria. It will also help to equip youths with positive attitudes, rational understanding and skills that will make them responsible citizens and future leaders. 


\section{Promotion of cultural integration}

Professional guidance counsellors can do this through the promotion of inter-ethnic group marriages, sports, students exchange programme, etc. since these things have very high potentials of enhancing inter-ethnic group understanding and tolerance.

Behavior modification: The application of appropriate behavior modification techniques by the counsellor in modifying inappropriate/maladaptive behaviours of Nigerians will go a long way in helping them to live in a manner that they will be useful to themselves and the Nigerian society. Counsellors can also help to develop new skills, encourage peaceful co-existence among various ethnic groups, and improve their communication and negotiation skills.

\section{Conflict management}

Since ruga has heightened inter-ethnic group distrust, fears, anxiety and conflicts in Nigeria, the counsellor should apply conflict management techniques of collaboration, compromise, accommodation and avoidance in helping the people to resolve their differences. Using collaboration will help the counsellor to explore the differences of the people and come up with alternatives and mutually satisfying solution while compromise will enable the counsellor to guide Nigerians in promoting peace and unity by splitting the differences among them so that the solution partially satisfies all ethnic groups. On the other hand, accommodation technique will enable the counsellor to help various ethnic groups to engage in self-bargaining. Lastly, avoidance technique will enable the counsellor to persuade various differing ethnic groups to withdraw or postpone unnecessary confrontations.

\section{References}

Adetayo, O., Onojeghen, T., Muhammed, U., Ogundele, K., Adepegba, A. \& Baiyewu, L. (2019). Ruga settlement: MBF, SMELF, Reps., others fault plan. Punch news, July 1. Retrieved on 15/08/2019 from https://punchng.com/rugasettlement-mbf-smblfrepc-others-fault-plan.

Agbakwuru, C. (2012). Guidance and Counselling in Non-school settings. Owerri: Joe Mankpa Publishers.

Agbakwuru, C. (2003). Obstacles to national integration and counselling implications. Knowledge Review, 7(3), 98-102.

Bankole, I. (2019). The true meaning of Ruga. Vanguard news, July 2. Retrieved on 17/08/2019 from https://www.vanguardngr.com/2019/07/time-true-meaning-ofruga.

Global Terrorism Index (2018). Measuring the impact of terrorism. Sydney: Institute for Economics and Peace.

Ojo, E. (2009). Federalism and the search for national integration in Nigeria. African Journal Political and International Relations, 3(9), 384-395.

Toromade, S. (2019). Controversy over Buhari's Ruga settlements explained. Pulse news, July, 2. Retrieved on 15/08/2019 from https://www.pulse.ng/news /local/rugacontroversey-over-buharis-settlementsexplained/wlrex8g. 